\title{
The Influence of Digital Games Based Learning on Students' Learning Outcomes and Motivation
}

\author{
Rahmat Yusny \\ UIN Ar Raniry Aceh \\ Jl. Syech Abdurra'uf Kopelma Darussalam Banda Aceh \\ ryusny@gmail.com \\ Sarah Fitri \\ UIN Ar Raniry Aceh \\ Jl. Syech Abdurra'uf Kopelma Darussalam Banda Aceh \\ sarah_fitri24@yahoo.com
}

\begin{abstract}
There is no doubt that the emergence of today's digital age greatly affects the human life - including students in their educational life. In order to simplify the process of studying languages, especially English, many scientists and experts continue to find new and innovative methods. One of them is the method of Digital Games Based Learning (DGBL). However, the implementation effort of DGBL method to improve English language skills of students is still a matter of controversy. It is mainly caused by the use of game - which is assumed by the public just as merely means of entertainment rather than as a medium of learning. Judging on this reason, researchers are interested highlighting them to be their research. This research was conducted in order to view the significance and influence of DGBL in improving English language skills of students - particularly the ability to hear and read - as well as their motivation to learn. The study was conducted over five sessions in March 2013 with a sample of 13 students were selected at random stratification of 68 second -year student population PBI , Ar - Raniry UIN .Researchers collected data by applying the experimental use of games in the classroom, provide pre-test and post-test, as well as distributing
\end{abstract}


questionnaires dealing with motivation. From the analysis of quantitative data, it can be concluded that the method of Digital Games Based Learning (DGBL) can be used to improve student's achievement and learning motivation in learning English.

Keywords: Digital Games Based Learning (DGBL), Learning outcome, Motivation

\section{Abstrak}

Kemunculan era digital dewasa ini, tidak dapat dipungkiri, sangat berpengaruh terhadap kehidupan manusia-termasuk siswa dalam mengenyam pendidikan mereka. Guna mempermudah proses mempelajari ilmu bahasa, terutama Bahasa Inggris, banyak ilmuwan dan para ahli yang terus berupaya menemukan metode baru dan inovatif. Salah satunya adalah metode Digital Games Based Learning (DGBL). Akan tetapi, upaya pengimplementasian metode DGBL untuk meningkatkan kemampuan berbahasa Inggris siswa masih menjadi kontroversi. Hal ini tidak lain disebabkan oleh penggunaan game-yang diasumsikan oleh publik sekedar alat hiburan semata - sebagai media pembelajaran. Menilik pada alasan tersebut, peneliti tertarik mengangkat permasalahan ini ke dalam penelitiannya. Penelitian ini dilakukan guna melihat signifikansi serta pengaruh DGBL dalam meningkatkan kemampuan berbahasa Inggris mahasiswa-terutama kemampuan mendengar dan membaca-serta motivasi belajar mereka. Penelitian dilakukan selama lima sesi pada bulan Maret 2013 dengan jumlah sampel 13 mahasiswa yang dipilih secara stratifikasi acak dari 68 jumlah mahasiswa PBI tahun kedua, UIN Ar-Raniry. Peneliti mengumpulkan data dengan mengaplikasikan penggunaan game di kelas eksperimen, memberikan pretest dan posttest, serta mendistribusikan kuisioner motivasi. Dari hasil analisis data secara kuantitatif, dapat disimpulkan bahwa metode Digital Games Based Learning (DGBL) dapat meningkatkan prestasi serta motivasi belajar mahasiswa dalam mempelajari Bahasa Inggris.

Kata kunci: Digital Games Based Learning (DGBL), Prestasi, Motivasi 


\section{Introduction}

The method in which student's speaking, listening, writing and reading abilities can be improved are becoming critical issues in which English is used as foreign language. Therefore, developing effective method to increase students' performance as both language learner and language user, and thus, enhancing students' English learning achievements has become an important topic.

To assist students with developing foreign language proficiency, second language teaching methods have begun to embrace the use of technology, specifically Computers-Assisted Language Learning (CALL) tools (Alatis, 1983; Pusack, 1981; Soper, 1982; Stevens, 1983, as cited in Levent, 2009: 45). One of methods that use Computer-Assisted Language Learning tools is learning through digital games. Prensky (2001: 5) used term "Digital Games Based Learning" to denote the use of computer game in educational content. Digital Games Based Learning is a profoundly new learning method that integrates the use of digital game on learning environment.

Although game is most often thought as a pure entertainment, it is important to actually know that it can be enormously powerful tool used to learn. Prensky (2006) stressed that digital game works as learning tool since "all games [basically] already cause player to learn". Findings from many researchers strengthen such acclaim as they found that digital game has enormously increased students' learning achievement, especially in learning language (Liu and Chu, 2010; Muller, n.d.; Panoutsopoulos and Sampson, 2012).

Prensky (2001:3) described "the process of game playing [as] engaging," so much that it brings together a great deal of motivation. 
Therefore, combining games with learning can add potential motivation, massive enough to let the learners stick with their learning process. Levent (2009: 46) further remarked that digital game helps the process of learning to become more engaging as it adds fun and excitement to help students feel more relaxed and comfortable. Purushotma (2005) has suggested that games can be so highly motivating that they can even cause addictive behavior as cited in Levent (2009: 46).

As cited in Prensky (2006: 1), Akerman (n.d.) affirmed that "play (game) is our brain's favorite way of learning things." Thus, learning new things by playing game can be one of the most engaging as well as effective ways to perceive data to our brain. The fact that people feel better, get less tired, and are highly motivated when they do things they enjoy, such as playing games, is the main idea of creating Digital Games Based Learning method.

Greatly interested with the use and development of Digital Games Based Learning (DGBL) method in English language learningespecially in enhancing students' reading and listening skills as well as their learning motivation - the researchers decided to strive this research to address the following two major aims:

1. To know if adventure game enhances students' English receptive skills

2. To find out the influence of DGBL towards students' learning motivation

\section{Hypothesis}

The hypothesis of this research is formulated as follow: 
"Digital Games Based Learning does influence students' learning outcomes and motivation"

\section{Digital games based learning}

There were two essential premises explaining the existence of digital games based learning (Prensky, 2006: 1). The first premise is that today's learners have changed in some fundamental ways. The fact that students nowadays living in digitally enhanced world, are somewhat have different way of thinking than what former students had. The second premise is that computer can provide new way to motivate today's students to learn. If one could think what game is actually best at, it would be based on the fact that it could provide motivation to its players. As mentioned by Anyaegbu (2012) "Games are often used for motivational or fun purposes."

Therefore, keeping the students motivated enough (to stick with their educational life) is a very critical matter faced nowadays. Learning methods that were effective in motivating learners in the past might not be able to motivate the learners of today. That is why the proponents of digital games based learning believed (Prensky, 2001; Pivec\&Dziabenko, 2003) that digital games based learning is the learning method that could foster not only students' learning achievement but also their inner motivation.

However, the use of game as a profoundly new learning method has been thoroughly criticized. As per saying goes "there are always two sides of a coin." While one side sees the emergence of digital games based learning as a bright light and solution in improving both students' achievements and motivation, the rest sees it as a merely exaggerated 
misled effort in combining two radically different things: serious, bookoriented, fixed purposed, rigid activity named learning, with carefree, fun-oriented, time-wasting activity called game.

\section{Positive effect of gaming in learning}

Games are effective not because of what they are, but because of what they embody and what learners are doing as they play a game (Richard Van Eck, 2006). "Games create an environment where education is mostly learner-centered, with a good opportunity for socialization when they are well-organized, and awakening the will to win and competitive desire inside people"(Squire, 2003: 5).Moreover, game presents simulated situation that often extracted from real world. Students think and understand better when they learn something they have been familiar with. Gee (2003) as cited in McClarty et al. (2012) pointed out "games present a similar situation through simulation, providing us the opportunity to think, understand, prepare, and execute actions".

Another learning benefit one can get from game playing is derived from the fact that game provides opportunities to continue practice despite repeated failures. It also presents immediate feedback and clear objectives. This allows players to change their game play in order to improve their performance and reach their goals.

Game is said to be particularly effective when "Designed to address a specific problem or to teach a certain skill” (Mitchell and Savill-Smith, 2004: 19), for example in encouraging learning in subjects areas such as math, physics and language, where specific objectives can be stated, or when chosen selectively to fulfill the objective intended 
aforementioned of playing the game, for instance: playing game to enhance spatial, problem-solving and strategic ability or to obtain new knowledge.

\section{Negative effect of gaming in learning}

As highlighted by Clark (2003) as cited in Mitchell and SavillSmith (2004), there are a number of risk factors that can negatively give impact on learning via computer games:

1) Game objectives may not be compatible with learning objectives.

2) Games can distract from learning as players concentrate on completing, scoring, and winning instead of focusing on learning.

3) Games require suspension of belief; it may be difficult to retain learning acquired in that state

4) Failure to reach male and female players to the same extent

5) Games risk the learners becoming non socialized people as gaming world is then literally seen as their world instead of their societies (pp. 22-23).

Aside from the bad effect of game is causing on learners, game in general induces severe effects of frequent playing for gamers. This includes health issues, psycho-social issues, and changes in behavior. Hence, players definitely in need to have a control and a good selfmanagement in playing the game and also a good sense of selection in choosing age and task appropriate game. 


\section{Learning outcomes}

Learning outcomes measure final result of intervention or program given to the students. It should be measurable as it will identify or observe what the students will achieve, should be able to do, and will know as the effect of the intervention given beforehand. Thus, immediate evidence of these collected knowledge, skills, and ability gathered after intervention is what is called outcomes.

A learning outcome is a written statement of what the successful student/learner is expected to be able to do at the end of the module/course unit, or qualification. The key aspect each of the definitions has in common is the desire for more precision and consideration as to what exactly a learner acquires in terms of knowledge and/or skills when they successfully complete a period of learning (Adam, 2004, p. $6)$.

\section{Game and reading comprehension}

Aside from the importance of cognitive and metacognitive strategies, a few studies have addressed the issues related to "motivation" and "engagement" when it comes to reading comprehension and the way to enhances it. As Guthrie et al. (2006) put it:

Engaged reading is based on motivational and cognitive characteristics of the reader...who is intrinsically motivated, builds knowledge, uses cognitive strategies, and interacts socially to learn from text. These engagement processes can be observed in student's cognitive effort, perseverance, and self-direction in reading (p. 404).

Encouraging learners to reading comprehension can be done by selecting appropriate materials, especially for young readers in their early stages of learning. This selection is very crucial considering the number of selected 
readers in recent times. That is why-in motivating readers of todaymany educational practitioners have begun to embrace game as one of the methods used in enhancing students' reading achievement.

Being labeled as one of solutions in motivating language learner, games as Carlson (1952) as cited in Meizaliana (2009:53) described “. . . are activities used to provide a fun and more relax atmosphere especially ... for student to acquire a second or foreign language." Thus, games are believed to help enhancing students' motivation to learn to read and later to read to learn by providing various contexts of learning materials in a more fun and engaging way.

\section{Game and listening comprehension}

Listening as an active process requires conscious attention and interests as well as physical involvement. Students who indicated high levels of motivation appeared to engage in listening more. "Motivation and metacognition appear to be elements that are part of clusters of variables contributing to variance in L2 listening" (Vandergrift, 1997: 196). Listening to what learners want to listen to and want to try to comprehend might motivate them to listen and to keep on learning. These want and interest might appear in when someone touches with different, unusual way of learning, thus commended on using game in learning language.

As Verdugo and Belmonte (2007: 87) pointed out: "Digital technology for students, if appropriately selected and organized, can offer a range of opportunities to develop foreign language listening and proficiency in a playful and enjoyable context." Therefore, in order to 
motivate and to enhance students' listening ability, one can afford to use appropriate, task-oriented, listening-produced game.

\section{Game enhances learning motivation}

The first thing one might expect to see while playing game is an increasing motivation. Common wisdom suggests that games are at least motivating, if not educational. Game embodies aspects and characters that engage learners to play.

Games contain the pieces necessary to engage students and help them enter a state of flow where "they are fully immersed in their learning environment and energized and focused on the activity they are involved in" (Csikszentmihalyi, 1990, as cited in McClarty et al., 2012: 14). When complete attention is devoted to the game, a player may lose track of time and not notice other distractions. Purushotma (2005) as cited in Levent (2009: 46) further added that "games can be so highly motivating that they can even cause addictive behavior."

On the other hand, game also creates fantasy, imaginary world which has rich visuals and plenty aesthetics aspects. Such things might attract awe and excitement from its players as it is considered as unique and recognizable feature. Another aspect of game that attains interest is its clear objectives. "Games are played to win or achieve a goal ... The key to motivation is winning while remaining challenged" (Becta, 2001: 1). Eventually, all "these components can increase student engagement, and student engagement is strongly associated with student achievement" (McClarty et al., 2012). 


\section{Research Design}

\section{Participants}

The population of the study was 68 English Department of IAIN Ar-Raniry students year 2011. The researchers used stratified random sampling technique to specify and determine the final samples of this research. Stratified random sampling is sampling technique which was based on diversities or stratified qualifications and characteristics that targeted population has (Prasetyo \& Jannah, 2009). The researchers stratified population based on students' game playing frequency and students' interest in game playing.

The researchers used preliminaries questionnaire as a basis to determine their strata. The researchers distributed the questionnaire to all English department students year 2011and there were 68 students responded to the questionnaire. Final samples were 13 students whom the researchers selected after careful consideration based on end result of preliminaries questionnaire.

\section{Data collection}

This study was a quantitative research. It also applied preexperimental design with one group pretest-posttest design. According to Sugiyono (2008), one-group pretest-posttest design is a design in which the experimental group experiences both pretest and posttest during the experiment. Further, the data was collected through experimental treatment using digital game, pretest and posttest, and motivational questionnaire. The process of collecting the data would be picturised as follow: 


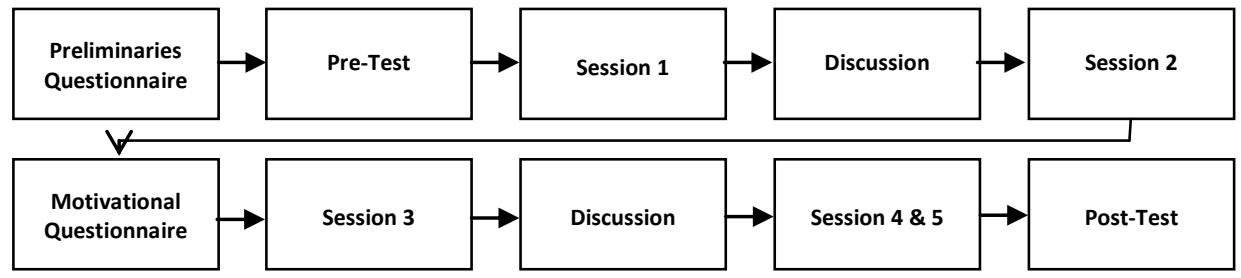

Figure 1: Diagram Outlining the Procedure of The Case Study

\section{Digital game}

The game used in this research was "Dream Sleuth". The game was comprised as adventure, point-click, and hidden-object game. This game used as an intervention for five-meeting research.
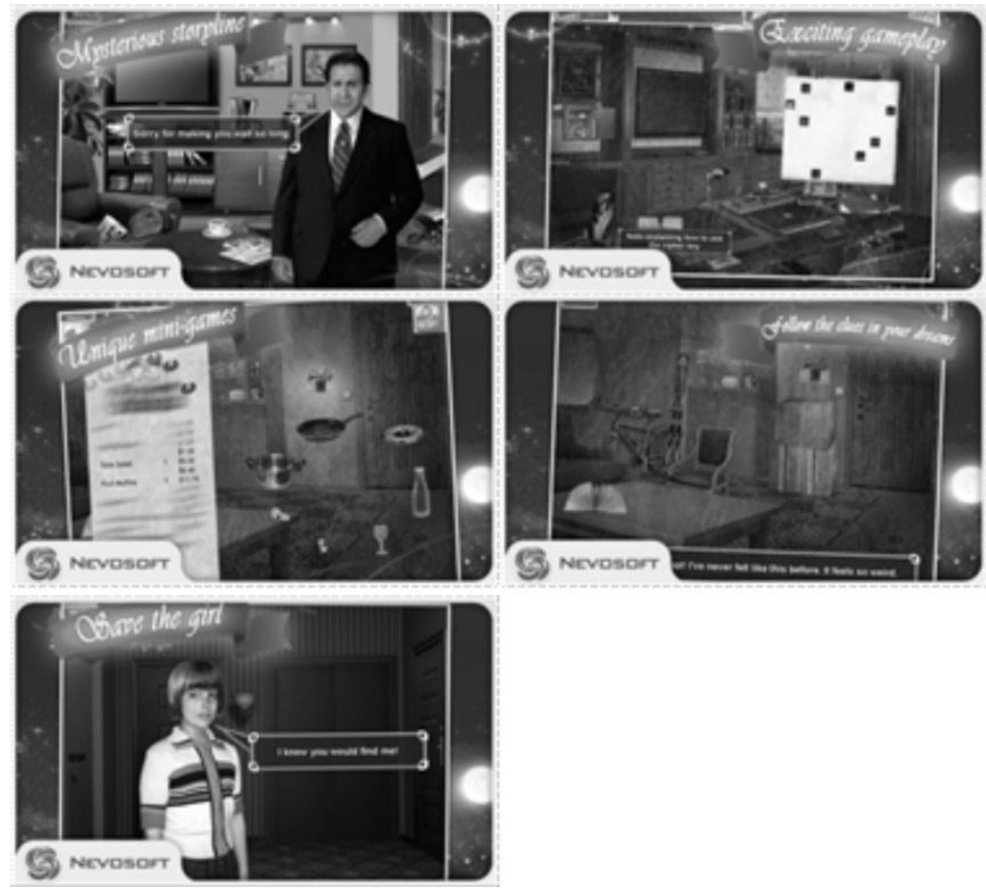

Figure 2: "Dream Sleuth" Screenshot

The selection of Dream Sleuth as intervention in this study was for the very reason of finding out appropriate game to foster English 
language learners' ability. Looking at how the game had in plate, this game offered mysterious storyline, unique mini games, exciting game play, and the foremost reason of having quite plenty of language learning benefits - especially reading and listening benefits.

\section{Tests}

The researchers handed out two tests for the experimental class: pre-test and post-test. Pretest was given at the beginning of the meeting, before the treatment conducted. Whereas post-test would be given at the end of the meeting, immediately after giving class treatment.

Pre-test was distributed with the aim of measuring the students' initial learning achievements before given the treatment. On the other hand, post-test had a purpose of measuring the improvement or differences in students' learning outcomes after being treated with the game. Both were necessary for the researchers to obtain the data as in to analyze whether there would be influences of digital game based learning on students' learning outcomes or not. The researchers intended to see students' learning outcomes. In particular, they wanted to find out two mainstream students' English learning outcomes, which were listening and reading. Therefore, in designing the test, the researchers created two parts of the test: listening comprehension and reading comprehension test.

Listening part consisted of four sections: section I, II, III, and IV. Each section of listening test comprised of five questions. In designing the listening part, the researchers excerpted the audio materials originated from Dream Sleuth game. They used Audacity, an audio editing 
software, to record, select, part, and save listening part in one complete format of listening material. Meanwhile, reading part consisted of two reading texts: reading text $\mathrm{I}$ and II. Each reading text has ten comprehension questions. In selecting reading texts, the researchers carefully examined reading texts and their correlation with the treatment. Reading text I was Aesop fables story, while reading text II was selected based on the theme used in "Dream Sleuth" game.

Table 1

Sample of Test

\begin{tabular}{|l|l|}
\hline \multirow{5}{*}{ Listening Part } & $\begin{array}{l}\text { Grandma : Happy birthday grandma! } \\
\text { Catherine } \\
\text { Thank you. } \quad \text { It's going to be a crazy day today with } \\
\text { So many }\end{array}$ \\
\hline \multirow{5}{*}{ Reading Part } \\
\\
According to the writer, what is the true nature of \\
the nurse? \\
(A) She is caring \\
(B) She is tricky and mean \\
(C) She is evil and hateful \\
(D) She is truthful
\end{tabular}

\section{Questionnaire}

The researchers applied questionnaire in order to perceive students' learning motivation. Questionnaire was distributed in the middle of treatment, right after the third session of game playing. Questionnaire used in this research was Learning Motivation through Game Playing Questionnaire (LMGP-Q). The questionnaire was adapted from Keller's ARCS model used by Kebritchi (2008). The questionnaire consisted of 20 questions with 14 non reversed questions and six reversed 
questions. Each item of ARCS Model (Attention, Relevance, Confidence, and Satisfaction) comprised of five questions.

Table 2

LMGP-Q's List of Questions

\begin{tabular}{|c|c|c|c|}
\hline 1. & $\begin{array}{l}\text { I think this game will be } \\
\text { challenging, but neither too } \\
\text { easy, nor too hard for me. }\end{array}$ & 11. & $\begin{array}{l}\text { The game is relevant to my } \\
\text { interests. }\end{array}$ \\
\hline 2. & $\begin{array}{l}\text { There is something interesting } \\
\text { about this game that will } \\
\text { capture my attention. }\end{array}$ & 12 & $\begin{array}{l}\text { It is clear to me how people } \\
\text { use the game to improve } \\
\text { their English skills }\end{array}$ \\
\hline 3. & $\begin{array}{l}\text { This game seems more } \\
\text { difficult than I would like for } \\
\text { it to be }\end{array}$ & 13. & $\begin{array}{l}\text { I will really enjoy } \\
\text { completing the task in this } \\
\text { game }\end{array}$ \\
\hline 4. & $\begin{array}{l}\text { I believe that completing the } \\
\text { task in the game will give me } \\
\text { a feeling of satisfaction. }\end{array}$ & 14. & $\begin{array}{l}\text { After working on this game } \\
\text { for awhile, I believe that I } \\
\text { will be confident in my } \\
\text { ability to successfully } \\
\text { improve my English skills }\end{array}$ \\
\hline 5. & $\begin{array}{l}\text { It is clear to me how this } \\
\text { game is related to things I } \\
\text { already know. }\end{array}$ & 15. & $\begin{array}{l}\text { I think that the variety of } \\
\text { materials, tasks, illustration, } \\
\text { etc., will help keep my } \\
\text { attention on this game. }\end{array}$ \\
\hline 6. & $\begin{array}{l}\text { I believe this game will gain } \\
\text { and maintain my interest }\end{array}$ & 16. & $\begin{array}{l}\text { The technology used to } \\
\text { deliver this the game may be } \\
\text { frustrating/ irritating. }\end{array}$ \\
\hline 7. & $\begin{array}{l}\text { I believe that the tasks } \\
\text { contained in this game will be } \\
\text { important to improve my } \\
\text { English skills }\end{array}$ & 17. & $\begin{array}{l}\text { It will feel good to } \\
\text { successfully complete this } \\
\text { game. }\end{array}$ \\
\hline 8. & $\begin{array}{l}\text { As I learn more about this } \\
\text { game, I am confident that I } \\
\text { could learn English through } \\
\text { playing }\end{array}$ & 18. & $\begin{array}{l}\text { The contents of this game do } \\
\text { not include information that } \\
\text { will be useful to me. }\end{array}$ \\
\hline 9. & $\begin{array}{l}\text { I believe that I will enjoy this } \\
\text { game so much that I would }\end{array}$ & 19. & $\begin{array}{l}\text { I do NOT think that I will be } \\
\text { able to really understand }\end{array}$ \\
\hline
\end{tabular}




\begin{tabular}{|l|l|l|l|}
\hline & $\begin{array}{l}\text { like to know more about the } \\
\text { learning I got while playing } \\
\text { the game }\end{array}$ & & what I learn from the game \\
\hline 10. & $\begin{array}{l}\text { The game seems dry and } \\
\text { unattractive. }\end{array}$ & 20. & $\begin{array}{l}\text { I do not think that this game } \\
\text { will be worth my time and } \\
\text { effort. }\end{array}$ \\
\hline
\end{tabular}

This questionnaire used Likert Scale measurement. There were five scales used in this Likert scale, namely: Not True $=1$; Slightly True $=2$; Moderately True $=3$; Mostly True $=4$; and Very True $=5$. There were the items marked reversedwhich are stated in a negative manner. For the reversed questions (item 3 , item 10 , item 16, item 18, item 19, and item 20), researcher would use reversed scoring. That is for these items, $5=1,4=2,3=3,2=4$, and $1=5$. The range of score for this questionnaire is: $20-35$ indicates very low learning motivation; $36-51$ indicates low learning motivation; $52-67$ indicates moderate learning motivation; 68 - 83 indicates high learning motivation; and $84-100$ indicates very high learning motivation.

Table 3

Reversed and Non-Reversed Motivational Questionnaire's Questions

\section{Items} Questions

\begin{tabular}{lcc}
\cline { 2 - 3 } & Non Reversed & Reversed \\
\hline Attention & $2,6,15$ & 10,16 \\
Relevance & $5,7,11,12$ & 18 \\
Confidence & $1,8,14$ & 3,19 \\
Satisfaction & $4,9,13,17$ & 20 \\
\hline
\end{tabular}

\section{Research result}

\section{Students' learning outcomes}

Through the use of tests, the researchers found necessary data needed to figure out the answer whether game method applied was 
significantly influential to enhance students' learning outcomes. In analyzing the data from the tests, the researchers would use statistical computing program called SPSS (Statistical Product and Service Solution).

Table 4

Frequencies Table of Pre-test and Post-test

\begin{tabular}{llll}
\hline & Pretest & Posttest \\
\hline N $\quad$ Valid & 13 & 13 \\
\multicolumn{1}{c}{ Missing } & 0 & 0 \\
Mean & 54.2308 & 71.3462 \\
Median & 57.5000 & 72.5000 \\
Std. Deviation & 9.48599 & 6.00481 \\
Variance & 89.984 & 36.058 \\
Minimum & 40.00 & 60.00 \\
Maximum & 70.00 & 80.00 \\
\hline
\end{tabular}

Based on the analysis of pretest and posttest, the researchers found that there was difference between mean of pretest (54.23) and posttest (71.35). From these data alone, it can be inferred that there was difference of students' learning outcomes before and after getting the treatment. To further analyze the improvement of students' learning outcome, the researchers used formula of paired samples $t$ test, finding that $t$ value was significantly different from $t$ table and $p$ value was much more less than standard sig. value of 0.05 . With $-t$ value $<-t$ table $(-6.683$ $<-2.179)$ and $p$ value $<0.05(0.000<0.05)$, meaning that the alternative 
hypothesis stating significant improvement in learning outcomes following the treatment using digital game was statistically accepted.

Table 5

Paired Samples T Test

\section{Paired Differences}

Std. $95 \%$ Confidence

Sig.

Std. Erro Interval of the

Mean Devia $r$ Difference

$\mathbf{T}$

(2tion Mea

Lower Upper

ed)

n

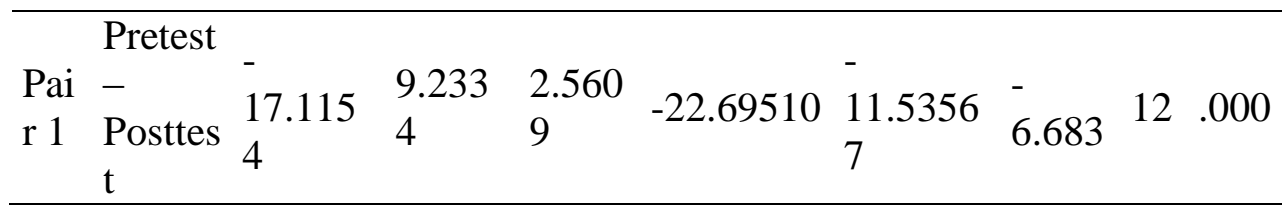

As many proponents of DGBL claimed that game is significantly influential to students' achievements if it is appropriately selected. Thus, in regard of such statement, the researchers used the formula of Effect Size to confirm digital game's treatment significance.

$E S=\frac{\bar{x}_{\mathbf{2}}-\bar{x}_{\mathbf{1}}}{S D}$

$E S=\frac{71.35-54.23}{9.49}=1.8$

In classifying the criteria of effect size number, the researchers used classification designed by Glass (n.d., as cited in Sutrisno, 2010):

$E S \leq 0.2 \quad$ : classified as low

$0.2<E S \leq 0.8 \quad$ : classified as medium

$E S>0.8 \quad:$ classified as high 
With score 1.80 , it can be concluded that game did have significant influence on students' learning outcomes. Above all, according to scale of effect size range from Glass, this number of effect size indicated high effect.

\section{Students' learning motivation}

The researcherss distributed motivational questionnaire to their participants. The questionnaire was adapted from Keller's ARCS model employed by Kebritchi (2008), indicating students' learning motivation toward the use of digital game. To suit the purpose of their study, the researcherss adapted questions and scales in their designated questionnaire.

Learning Motivation through Game Playing (LMGP-Q), as it was named, was distributed during the treatment. The researcherss used both numerical and descriptive analysis to explain the questionnaire. After getting the result for questionnaire, the researcherss found that among 13 samples, one student was classified as moderate level of motivated learner, eight as highly motivated learners, and four as very highly motivated learners.

Table 6

The Description of Students' Questionnaire Results

\begin{tabular}{llll}
\hline No. & Initials & Score & Level \\
\hline 1. & N.F & 82 & High \\
2. & I.P & 79 & High \\
3. & Y.A & 94 & Very High \\
4. & S.F.Y & 88 & Very High \\
5. & I.R & 86 & Very High \\
6. & N.U & 80 & High
\end{tabular}


7. Aul.

High

8. D.R.R

69

High

9. R.A

60

Moderate

10. O.R.P

83

High

11. M.D.U

75

12. N.M

87

High

13. N.H

80

Very High

79.54

High

Mean

In accordance of each items in ARCS model, with Attention $(\mathrm{M}=$ 4.14), Relevance ( $M=3.88)$, Confidence $(M=3.89)$, and Satisfaction ( $M$ $=4.02$ ) resulting in positive attitude and motivation from participants in general. These result demonstrated participants' positive interest, confidence, satisfaction, and attitude toward using game to enhance their learning experience and motivation.

Table 7

Mean of ARCS Model Items

\begin{tabular}{cc}
\hline Items & Score Average (Mean) \\
\hline Attention & 4.14 \\
Relevance & 3.88 \\
Confidence & 3.89 \\
Satisfaction & 4.02 \\
\hline
\end{tabular}

\section{Hypothesis}

Now that the result of the research had been found, the researcherss could analyze the hypothesis. Statistically speaking, hypothesis "Digital Games Based Learning does influence students' learning outcomes and motivation" was accepted, as the result indicates improvement on students' learning outcomes $(-6.683<-2.179)$ and positive indicator for learning motivation $(\mathrm{M}=79.54)$. Eventually, it can be summarized that digital game based learning has significant influence 
on students' learning outcomes and motivation. In the end, concluding that formulated hypothesis is accepted.

\section{Conclusions}

The purpose of this study was to examine the influence of digital games based learning on students' learning outcomes and motivation. The population of the study was 68 English Department students year 2011. The total 13 samples were derived from the use of stratified random sampling which divided the population into three, from which the researchers selected her samples.

This study was a quantitative research. It also applied preexperimental design with one group pretest-posttest design. The data was collected through experimental treatment using digital game, pretest and posttest, and motivational questionnaire. The process of collecting the data was held for five sessions in March, 2013.

In analyzing the data from the tests, the researchers used paired sample $t$ test to find out if there was difference of score following students' engagement in game-playing. Further use of effect size formula was also considered in order to find out how big of effect was actually the digital games based learning method had in enhancing students' learning outcomes. Moreover, in analyzing the data of motivational questionnaire, the researchers was setting out standard value for each item and reversed item, accumulating them into final score and describing them into three level group of students' learning motivation. Since the researchers used Keller's ARCS model, the researchers then analyzed each ARCS item-considering its dimensional difference 
within learning motivation. After analyzing the data and discussing its result, provided below are the conclusions of study:

1. There was significant improvement of students' learning outcomes, in particular reading and listening skills, after indulging within the treatment using digital game. The significance of digital game to enhance students' English skills was shown through the result of data analysis. The difference of pretest's mean $(\mathrm{M}=54.23)$ to that of posttest's $(M=71.35)$ signaling that there was difference of students' before and after treatment's score. Further use of paired samples t test strengthened the difference, by resulting in $-t$ value (-6.683) lower than that of $-t$ table's (-2.179). The significance of students' improvement were statistically calculated using effect size which resulted in high significance level of influence of digital games based learning on students' learning outcomes. In summary, it can be concluded that DGBL did enhance students' learning outcomes.

2. There was influence of digital games based learning toward students' learning motivation since the result of motivational questionnaire showed that students mostly reacted positively toward the use of game to learn English. Mean score $(M=79.54)$ was the proof that in average, participants indulged in this research were indicated as highly motivated learners. This indication of high learning motivation was clearly shown during the researchers' research-having seen her participants playing continuously with a lot of curiosity; breaking in joy for finishing certain levels; or simply seen them focusing intensely since the level was pretty difficult. In the end, it all proved that digital games based learning indeed has effect on students' learning motivation. 
3. Through the analysis of Keller's ARCS items, the researchers could deduce the following assumptions: (1) Majority of students believed that digital games based learning could increase their interest and attention toward English learning as it provided various tasks, rich visuals, and challenging levels, all provided in English; (2) students realized that the game, if appropriately selected, could enhance their English learning, especially in reading and listening; and (3) students would feel satisfaction, excitement, challenge, and accomplishment once they finish the game. These resulting in students' feeling more motivated and enthusiastic toward learning English through gameplaying.

\section{Future works}

For future researchers, the researcherss suggest to ensue further exploration toward the effect of digital games in learning environment. The following issues can be considered for future research: Firstly, it is helpful to examine the effects of the same or similar game used in this study with different participants. Secondly, various findings for the influence of the games in this study, justify further investigation to better identify the cause of the game effects on achievement and motivation. Thirdly, as this study relied only on statistical calculation, further and deeper investigation using qualitative instruments on effects of the games on motivation should be conducted. Finally, the researchers recommended other researchers to work on the same background with a more complete design and a greater number of participants. 


\section{References}

Adam, S. 2004. Using Learning Outcomes. In Report for United Kingdom Bologna Seminar, Bologna.

Guthrie, J. T., Wigfield, A., Humenick, N. M., Perencevich, K. C., Taboada, A., \& Barbosa, P. 2006. Influences of Stimulating Tasks on Reading Motivation and Comprehension. The Journal of Educational Research, 99(4), 232-246.

Levent, U. 2009. An Evaluative Checklist for Computer Games Used for Foreign Language Vocabulary Learning and Practice: Vocaword Sample. Novitas-ROYAL, 3(1), 45-59.

McClarty, K. L., Orr, A., Frey, P. M., Dolan, R. P., Vassileva, V., \&McVay, A. 2012. A Literature Review of Gaming in Education. London: Pearson Pubs.

Meizaliana, M. 2009. Teaching Structure through Games to the Students of Madrasyah Aliyah Negeri 1 Kepahiang, Bengkulu (Doctoral dissertation). Universitas Diponegoro, Semarang, Indonesia.

Mitchell, A., \&Savill-Smith, C. 2004. The Use of Computer and Video Games for Learning: A Review of the Literature. Wales: Learning and Skills Development Agency.

Prasetyo, B., \&Jannah, L. M. 2006. Metode Penelitian Kuantitatif. Jakarta: Raja Grafindo Persada.

Prensky, M. 2001. The Digital Game-based Learning Revolution. Retrieved from http://www.marcprensky.com/.../prensky\%20\%20ch1-digital\%20game- on October 9, 2012.

Prensky, M. 2006. Computer Games and Learning: Digital Game-based Learning.Retrieved from http://www.marcprensky.com/.../prensky\%20-\%20ch1digital\%20game-... on October 9, 2012.

Squire, K. D. 2003. Video Games in Education. Int. J. Intell. Games \& Simulation, 2(1), 49-62.

Sugiyono. 2008. Metode Penelitian Pendidikan. Bandung: Alfabeta.

Vandergrift, L. 1997. The Comprehension Strategies of Second Language (French) Listeners: A Descriptive Study. Foreign Language Annals, 30(3), 387-409.

Verdugo, D. R., \& Belmonte, I. A. 2007. Using Digital Stories to Improve Listening Comprehension with Spanish Young Learners of English. Language Learning \& Technology, 11(1), 87-101. 